\title{
Öğretmenlerin Mesleki Çalışmalara İlişkin Metaforik Algıları*
}

\section{Metaphoric Beliefs of Teachers about Occupational Practices}

\author{
Yusuf TÜRKER ${ }^{* *}$ (D) Türkay Nuri TOK ${ }^{* * *}$ (DD
}

Received: 21 June 2018

Research Article

Accepted: 03 August 2018

ABSTRACT: The aim of this study was to examine the beliefs of teachers about occupational practices through the metaphors they developed. The occupational practices, mostly experienced in their own schools, held in September and June annually. The study was designed as a descriptive quantitative research comprising of 150 teachers. The research data was collected from those teachers of Muratpaşa district of Antalya through "Metaphors Teachers Survey Towards the Occupational Practices" developed by researchers. Data applied content analysis was divided into two categories "occupational practices" and "ideal occupational practices". Occupational practices period grouped into ten themes and ideal occupational practices grouped into nine themes. The important findings of study are that nearly all of the teachers have generated negative metaphors about the occupational practices and nearly all of the teachers have generated positive metaphors about the ideal occupational practices. The theme of "occupational practices as a wasted time and fruitless actions" has been the mostly observed metaphor theme and The theme of "ideal occupational practices as instructive actions and benefit-providing actions" has been the mostly observed metaphor theme.

Keywords: occupational practices, teachers' seminars, metaphor.

ÖZ: Bu çalışmanın amacı, öğretmenlerin geliştirdikleri metaforlardan yola çıkarak mesleki çalışmalar hakkındaki öğretmen görüşlerini belirlemektir. Mesleki çalışmalar, öğretmenler arasında seminer dönemi diye adlandırılan, haziran ve eylül aylarında ikişer haftalık periyotlarla düzenlenen çalışmalardır. Bu çalışma, nitel araştırma yöntemine uygun olarak tasarlanan betimsel bir araştırmadır. Araştırmanın çalışma grubunu Antalya İli Muratpaşa İlçesi'nde görev yapmakta olan 150 öğretmen oluşturmaktadır. Veriler, araştırmacı tarafından geliştirilen "Mesleki Çalışmalara Yönelik Öğretmen Metaforları Formu" aracılığıyla toplanmıştır. İçerik analizine tabi tutulan veriler "uygulanan mesleki çalışmalar" ve "ideal mesleki çalışmalar" diye iki kategoriye ayrılmıştır. Bu kategorilerden "uygulanan mesleki çalışmalar" kategorisi kendi içinde on temada, "ideal mesleki çalışmalar" kategorisi de kendi içinde dokuz temada gruplandırılmıştır. Çalışmanın en dikkat çekici bulgusunun, katılımcıların neredeyse tamamının uygulanan mesleki çalışmalara yönelik olumsuz metafor geliştirmesine karşın; çok büyük oranda katılımcının ise ideal mesleki çalışmalara yönelik olumlu metaforlar geliştirmeleri olduğu söylenebilir. "Uygulanan mesleki çalışmalar" kategorisinde, "sonuç doğurmayan eylemler olarak mesleki çalışmalar" ve "boşa geçen zaman olarak mesleki çalışmalar" temaları; "ideal mesleki çalışmalar" kategorisin de ise, "fayda veren eylemler olarak ideal mesleki çalışmalar" ve "öğretici olarak ideal mesleki çalışmalar" temaları en çok metafor üretilen temalar olmuştur.

Anahtar kelimeler: mesleki çalışmalar, öğretmen seminerleri, metafor.

\footnotetext{
* This article was presented at the 10th National Education Management Congress held on 7-9 May 2015.

** Teacher, Ministry of National Education, Antalya, Turkey, yusuf.turker@gmail.com

${ }^{* * *}$ Corresponding Author: Asst. Prof. Dr., İzmir Democracy University, İzmir, Turkey, turkaytok@gmail.com
}

Citation Information

Türker, Y., \& Tok, T. N. (2019). Öğretmenlerin mesleki çalışmalara ilişkin metaforik algıları. Kuramsal Eğitimbilim Dergisi [Journal of Theoretical Educational Science], 12(1), 274-297. 


\section{Giriş}

Günümüzde bir kişinin mesleği ile ilgili öğrenme sürecinin, okulda verilen eğitimin tamamlaması ile sona ermediği yönünde yaygın bir kabulün olduğu söylenebilir. Nerdeyse her meslek dalında duymaya alıştı̆̆ımız kongreler, seminerler, çalıştaylar, hizmetiçi eğitim çalışmaları gibi faaliyetler bu görüşü destekler niteliktedir. Öğretmenlere yönelik eğitim öğretim döneminin başında ve sonunda genellikle ikişer haftalık dönemler halinde düzenlenen mesleki çalışmalar da bu kapsamda değerlendirilebilecek etkinliklerdendir. Millî Eğitim Bakanlığı personeli olan bir milyon civarındaki öğretmen ile böylesine geniş çaplı ve maliyetli bir eğitim faaliyetine duyulan ihtiyacın altında yatan temel nedenin ise her alanda olduğu gibi eğitim alanında da yaşanan değişim ve dönüşüm hareketlerinin zorunlu kıldığı öğrenme ve mesleki gelişme ihtiyacı olduğu söylenebilir.

Bilgi çağı diye adlandırılan çağımız, paradigmaların çok kısa sürede eskiyebildiği, üretilen bilgi ve teknolojinin etkisi ile baş döndürücü değişimlerin yaşandığı bir dönemdir. Dolayısıyla değişimi anlama; günümüzü anlama ve anlamlandırmada anahtar konumundadır. Bu bağlamda meslekler ve örgütler değişimi anlamak ve değişimlerin ortaya çıkardığı meydan okumalarla baş edebilmek zorundadır. Aksi takdirde varlıkları uzun süreli olamayabilir. Bu kapsamda okullar ve okulların en önemli unsurlarından biri olan öğretmenler de değişimin yarattığı bu meydan okuma ile karşı karşıyadır.

Sanayi devrimi ile birlikte artan iş gücü ihtiyacının bir sonucu olarak eğitimin bugünkü bildiğimiz anlamda kitleselleştiği görülür. Kitleselleşen ve gelenekselleşen eğitimin Tezcan'ın (1996) ifadesi ile bir çeşit kültürü aktarma aracı olması ve Althusser'e (2016) göre bireye aktardığ ideoloji yoluyla devletin kendi varlığını sürdürmesinin bir yolu olması nedeniyle muhafazakâr bir özellik gösterdiği söylenebilir. Buna karşın bilimsel ve teknolojik alanda yaşanan baş döndürücü hızdaki gelişmelerin doğurduğu bilgi patlaması, günümüz toplumlarının ekonomik, kültürel ve sosyal anlamda büyük değişimler yaşamasına neden olmaktadır. Endüstri 4.0 tanımlaması ile popüler hale gelen bu değişim dalgası Lasi ve Kemper' in (2014) vurguladığı gibi sadece üretim süreçlerini değil bütün bir toplumu değiştirmektedir. $\mathrm{Bu}$ değişsim dalgas1 Dinçer'e (2003) göre kültür aktarma aracı olarak tutucu bir özelliği olan eğitimi, bu işlevini aşan biçimde toplumsal, ekonomik, kültürel, siyasal, teknolojik değişmelerden hem etkilenen hem de bu değişmeyi etkileyen bir kurum olmaya zorlamaktadır.

Çağımızda yaşanan değişim dalgası, eğitimden ve öğretmenden beklenenlerin de farklılaşmasına ve artmasına neden olmaktadır. Artan beklentilerin bir sonucu olarak aileler eğitimden ve öğretmenden çocuklarına sadece okuma yazma öğretmelerini veya bir üst öğrenim kurumuna hazırlamalarını istememekte, dünya ile rekabet edebilir bireyler yetiştirmelerini beklemektedir (Nartgün \& Kaya, 2016; Özkan, 2018). Eğitime ve öğretmenlere yönelik artan bu taleplere cevap verebilmek ise eğitim örgütlerinin ve öğretmenlerin kendilerini yenileyebilmelerini gerektirir. Başka bir anlatımla öğrenen bireylerden oluşan öğrenen örgütler değişime ayak uydurabilir, hatta değişimi yönlendirebilir. Özden (2008) öğrenen örgütü, örgütlerin deneyimlerinden ders alma yeteneği, değişen koşullara uyum sağlama becerisi ve örgütlerin kendi kendini yenileyebilen dinamik bir yapı kazanması şeklinde ifade etmektedir. Bu bağlamda okulların, değişimin etkisiyle yönlendirilen pasif unsurlar olmaktan çıkıp, değişimi 
anlayıp yönlendirebilen aktör konumuna gelmeleri sürecinde, öğrenen birer örgüt olmaları fark yaratan bir etki meydana getirebilir.

Örgütleri değişimin nesnesi olmaktan çıkarıp öznesi yapacak en önemli örgüt unsurunun insan olduğu söylenebilir. Bolman ve Deal'ın (2013) örgütü tanımlarken kullandıkları yapısal, politik, sembolik ve insan kaynakları çerçeveleri bir arada düşünüldüğünde bütün bu unsurları yaratan ve dönüştüren etkenin insan olduğu görülür. Bu bağlamda günümüz eğitim örgütleri olan okulların, klasik örgütlerin ihtiyaç duyduğu insan unsurundan daha farklı niteliklere sahip insan kaynaklarına ihtiyaç duyduğu söylenebilir. Çünkü öğrenen örgütler, öğrenmeyi öğrenmiş bireyler ve takımlar sayesinde kurulup çalıştırılabilir. Başka bir deyişle öğrenen örgüt olma, her şeyden önce örgütü oluşturan kişilerin öğrenmeyi öğrenmiş olmaları ile gerçekleşebilir. Hoskins ve Fredriksson'ın (2008) bir kişinin eğitim uygulamaları ile etkileşime girerek geliştirdiği bilgi, deneyim, değer ve eğilimlere dayanan genel yetenek olarak tanımladığı öğrenmeyi öğrenmek kavramını İnam (2014), dışımızdaki ve içimizdeki gerçekliğe karşı bir duruş, bir yaşama tarzı, bir yaşam biçimi olarak ifade etmekte; öğrenme ve yaşam deneyimleri karşısında tavrı olmayan, bu deneyimlerini gözden geçirmeyen, sürekli olarak kendini yenilemeyen ya da yenileme eğiliminde olmayan insanların öğrenmeyi öğrenmesinin mümkün olmadığını vurgulamaktadır.

Öğrenen örgüt olma yolundaki okullar, mümkün olan her firsatta öğretmenlerin öğrenmeyi öğrenmiş bireyler olmalarını desteklemelidir. Okul, öğretmenlerin deneyimlerini paylaşabildikleri, yeni şeyler öğrenebildikleri ortamları yaratarak ve öğrenmeyi öğrenmiş bireylerin varlığını kabul edip onurlandırarak, bu kavrama verdiği önemi açık bir biçimde ifade edebilmelidir. Bu kapsamda Millî Eğitim Bakanlığı mevzuatında yer alan mesleki çalışmalar öğretmenlerin öğrenmeyi öğrenmiş bireylere, okulların da öğrenen örgüte dönüşme çabalarına katkı sunabilir. Mesleki çalışmalar, Milli Eğitim Bakanlığı Ortaöğretim Kurumları Yönetmeliği (2016) ve Okulöncesi Eğitim ve İlköğretim Kurumları Yönetmeliği’nde (2014) “yönetici ve öğretmenlerin genel kültür, özel alan eğitimi ve pedagojik formasyon alanlarında, bilgi ve görgülerini artırmak, yeni beceriler kazandırmak, eğitim ve öğretimde karşılaşılan problemlere çözüm yolları bulmak, öğrencinin ve çevrenin ihtiyaçlarına göre plan ve programları hazırlamak ve uygulamak amacıyla derslerin kesiminden temmuz ayının ilk iş gününe, eylül ayının ilk iş gününden derslerin başlangıcına kadar; yıl içinde ise yıllık çalışma programında belirtilen sürelerde mesleki çalışma yapılır. Yönetici ve öğretmenlerin mesleki çalışmalarından azami verim elde edilebilmesi amacıyla okulun ve çevrenin ihtiyaçlarına göre, bunların dışındaki konular da belirlenebilir. Mesleki çalışma programı okul müdürlüğünce hazırlanarak öğretmenlere bir hafta önce duyurulur." şeklinde açıklanmaktadır. Mesleki çalışmalar gibi eğitim çalışmaları, öğretmenlerin niteliklerini yükseltme ve kendi potansiyellerini tam olarak kullanma becerisi kazanmaları açısından önemli bir süreçtir (Seferoğlu, 2004). Bu sürecin amacına ulaşması için çok iyi planlanması ve uygulanması gerekir. Öğretmen ancak bu sayede sürekli olarak kendini geliştirebilir ve çağın gerektirdiği eğitimsel etkinlikleri gerçekleştirebilir (Cerit, 2004).

Mesleki çalışmaların, uygulanan hali ile güçlü ve zayıf yönlerini ortaya koymak amaçlanan etkiye ulaşmada bir yol gösterici olabilir. Bu kapsamda mesleki çalışmalara yönelik gerçekleştirilen araştırmaları incelemek gerekir. Her yıl düzenlenen mesleki çalışma uygulamalarının etkililiği konusunda yaptığı araştırmada Direk (2012), seminer 
konularının seçiminde, hazırlanmasında ve raporlaştırılmasında öğretmen görüşlerinin alınmadığı, bu nedenle öğretmenlerin daha özgürce ve özgünce hareket etmesinin yararlı olacağı sonucuna ulaşmıştır. Büyükcan (2008) ilköğretim okullarında ders yılı başı ve sonunda uygulanan mesleki çalışmaların öğretmenlere orta düzeyde yararlı olduğu bulgusuna ulaşmıştır. Mesleki çalışmalarda öğretmenlerin; materyallerin eksik olması, çalışmalarının iyi planlanmamış olması, çalışma ortamının elverişsiz olması, iş birliği içinde çalışılmaması, öğretmenlerin motivasyonlarının sağlanmaması gibi güçlüklerle karşılaştıkları belirlenmiştir. Gökyer'in (2012) araştırmasına göre öğretmenler, mesleki çalışma konularının kendilerini geliştirici nitelikte olmadığını ve ihtiyaçları doğrultusunda belirlenmediğini düşünmektedirler. Sıcak ve Parmaksız (2016) mesleki çalışmalar kapsamında ihtiyaç analizi sürecinde öğretmenlerin rolünün olmadığı, mesleki çalışmaların öğretmenlerin mesleki gelişimine katkısının teorik düzeyde olduğu, düzenlenen hizmet içi eğitim faaliyetlerinde kullanılan yöntem ve tekniklerin uygun olmadığı, değerlendirme sürecinin yetersiz olduğu sonucuna ulaşmıştır. Alanyazın incelendiğinde, mesleki çalışmalar özelinde başka bir araştırmaya rastlanmazken; genel olarak mesleki çalışmaları da kapsayan hizmet içi eğitim faaliyetleri ile ilgili görece daha fazla araştırmanın olduğu görülür (Can, 2004; Demirkol, 2004; Dinçer, 2003; Aslan, 2015; Gökyer, 2012; Gülmez, 2004; Gültekin \& Çubukcu, 2008; Gültekin, Çubukcu, \& Dal, 2010; Günbayı \& Taşdöğen, 2012; Güneş, 2006; Nemli, 2017; Özen, 2006; Özsavc1, 2015; Saka, 2005; Tok \& Tok, 2009; Turgut, 2012).

Öğretmenlerin eğitim-öğretim yılının başında ve sonunda yaptıkları mesleki çalışmaları konu edinen bu araştırmada, öncelikle öğretmenlerin mevcut mesleki çalışmalar hakkındaki görüşleri alınmıştır. Ardından ideal diye tanımlayabilecekleri, bir başka deyişle olmasını arzu ettikleri mesleki çalışmalar hakkındaki görüşlerine yer verilmiştir. $\mathrm{Bu}$ açıdan öğretmenlerin eğitimle ilgili güncel gelişmeleri takip ederek niteliklerinin arttırılmasında önemli bir fırsat olan mesleki çalışmaların daha etkili hale gelmesine araştırmanın katkı sağlayabileceği öngörülmektedir.

Öğretmenlerin "uygulanan mesleki çalışmalar” hakkında sahip oldukları algı ile "ideal mesleki çalışmalar” hakkında tasarladıkları algılarını metaforlar aracılığıyla analiz etmeyi amaçlayan bu çalışmada aşağıdaki sorulara cevaplar aranmıştır:

- Öğretmenler "uygulanan mesleki çalışmalar" hakkında hangi metaforları kullanmaktadırlar?

- Ortak özellikleri dikkate alındığında "uygulanan mesleki çalışmalara" yönelik metaforlar hangi temalar altında toplanmaktadır?

- Öğretmenler “ideal mesleki çalışmalar” hakkında hangi metaforları kullanmaktadırlar?

- Ortak özellikleri dikkate alındığında "ideal mesleki çalışmalara" yönelik metaforlar hangi temalar altında toplanmaktadır?

\section{Yöntem}

\section{Araştırma Modeli}

Öğretmenlerin "mesleki çalışmalar" hakkında sahip oldukları algı ile "ideal mesleki çalışmalar” hakkında tasarladıkları algıları metaforlar aracılığıyla belirlemeyi amaçlayan bu çalışma bir durumu betimlemeye yönelik nitel bir araştırmadır. Morgan'a 
(1997) göre metaforlar betimleme amaciyla kullanıldığında bir durum, olay ve olgu var olduğu haliyle betimlenir, resmedilir. Veriler açık uçlu soruların yer aldığı formlar aracılığı ile toplanmıştır. Elde edilen veriler üzerinde içerik analizi yapılarak, bu verileri açıklayabilecek kavramlara ve ilişkilere ulaşılmaya çalışılmıştır. Bu amaçla elde edilen verilerin öncelikle kavramlaştırılması, ardından elde edilen kavramlar bağlamında organize edilmesi, son olarak da veriyi açıklayan temaların saptanması gerekmektedir (Yıldırım \& Şimşek, 2006).

\section{Katılımcilar}

$\mathrm{Bu}$ araştırma, 2014-2015 Eğitim-Öğretim Yılı'nda Antalya İli Muratpaşa İlçesi'nde görev yapmakta olan 150 öğretmenin katılımıyla gerçekleştirilmiştir. Araştırmanın katılımcıları amaçlı örnekleme yöntemlerine göre "kolay ulaşılabilir durum örneklemesi tekniği”" ile belirlenmiştir. Patton'a (2014) göre, amaçlı örnekleme zengin bilgiye sahip olduğu düşünülen durumların derinlemesine çalışılmasına olanak vererek olgu ve olayların keşfedilmesinde ve açıklanmasında yararlı olmaktadır. Kolay ulaşılabilir durum örneklemesi tekniği ise Yıldırım ve Şimşek’e (2006) göre, araştırmacının ancak bu örnekleme ulaşabilirim diyebileceği durumlarla ilgilidir ve araştırmaya hız ve pratiklik kazandırabilir.

Araştırmaya Antalya İli Muratpaşa İlçesi’nde görevli 160 öğretmen katılmıştır. 10 öğretmenin formları eksik doldurması nedeniyle araştırma kapsamı dışında tutulmuştur. Araştırmaya katılanların isimlerine yer verilmeyerek, kısaltmalar (örneğin birinci katılımcı yerine K1) kullanılmıştır. Araştırmaya katılan öğretmenlere ilişkin bilgiler Tablo 1'de belirtilmiştir.

Tablo 1

Çalışma Grubunun Özellikleri

\begin{tabular}{llll}
\hline Değişken & Kategori & N & $\%$ \\
\hline \multirow{2}{*}{ Cinsiyet } & Kadın & 93 & 62 \\
& Erkek & 57 & 38 \\
\hline \multirow{2}{*}{ Görev } & Sinı Öğretmeni & 54 & 36 \\
& Branş Öğretmeni & 96 & 64 \\
\hline \multirow{2}{*}{ Öğrenim Durumu } & Lisans & 145 & 96 \\
& Lisansüstü & 5 & 3 \\
\hline \multirow{3}{*}{ Görev Süresi } & $1-5$ yıl & 5 & 3 \\
& $6-10$ yıl & 24 & 16 \\
& $11-15$ yıl & 43 & 28 \\
& $16-20$ yıl & 38 & 25 \\
& 20 yıl ve üzeri & 40 & 26 \\
\hline
\end{tabular}

Tablo 1 ayrıntılı olarak incelendiğinde, katılımcıların büyük bir bölümünün cinsiyet değişkeni açısından kadın (\%62), görev değişkeni açısından branş öğretmeni 
(\%64), öğrenim durumu değişkeni açısından lisans mezunu (\%96) ve görev süresi değişkeni açısından da 11-15 yıl görev süresine (\%28) sahip oldukları görülür.

\section{Veri Toplama Aracı}

Araştırma verileri, uzman görüşü alınarak araştırmacılar tarafından hazırlanan ve iki bölümden oluşan formlar aracılığı ile toplanmıştır. Formların birinci bölümünde demografik bilgilere yönelik sorular varken, ikinci bölümünde katılımcıların mesleki çalışmalara yönelik sahip oldukları metaforları ortaya çıkarmak için öğretmenlerden, "Uygulanan mesleki çalışmaları canlı bir varlık, bir nesne, bir masal kahramanı ya da tarihsel bir kimliğe benzetmenizi istesem neye benzetirdiniz? Niçin?" ve "İdeal mesleki çalışmaları canlı bir varlık, bir nesne, bir masal kahramanı ya da tarihsel bir kimliğe benzetmenizi istesem neye benzetirdiniz? Niçin?" sorularını yanıtlamaları istenmiştir. Yıldırım ve Şimşek'e (2006) göre mutlaka "niçin” veya "neden” soruları sorulmalıdır. Çünkü metaforların gücünü bu sorular ortaya koyar. Her birey aynı veya benzer metaforlara farklı anlamlar yükleyebilir. Yüklenen bu anlamsal farklılıklar "niçin" veya "neden" gibi soruların sorulması ile ortaya konabilir.

\section{Verilerin Toplanması}

Araştırmada kullanılan veriler Antalya İli Muratpaşa İlçesi’nde yer alan ilk ve ortaokullardan toplanmıştır. Veri toplamak amacıyla geliştirilen formlar bizzat araştırmacı tarafından katılımcıların çalıştıkları kurumlar ziyaret edilerek dağıtılmıştır. Eğitim öğretim sürecini aksatmama ve öğretmenlerin görüşlerini rahatça yazabilmeleri için iki günlük süre yeterli görülmüştür. Sürenin sonunda gönüllü katılımcılar tarafindan doldurulan formlar, yine araştırmacı tarafından katılımcıların okullarına gidilerek doğrudan doğruya öğretmenlerden toplanmıştır.

\section{Verilerin Analizi}

Verilerin çözümlenmesinde içerik analizi kullanılmıştır. İçerik analizi söylemin görünen, kolayca yakalanan, sergilenmiş ve ilk bakışta algılanan içeriği yerine, gizil, üstü kapalı içeriğini ortaya çıkarmayı sağlamaktadır. Bu çalışmada içerik analizi yapılırken "kategorisel analiz tekniği” kullanılmıştır. Kategorisel analiz tekniği belirli bir mesajın önce birimlere bölünmesini ve ardından bu birimlerin, belirli kriterlere göre kategoriler halinde gruplandırılması şeklinde açıklanabilir. Kategorilerin homojen, ayırt edici, objektif olması, bütünsellik taşıması, amaca uygun ve anlamlı olması gerekmektedir (Yıldırım \& Şimşek, 2006). Araştırma verilerinin elde edildiği formlarda öğretmenler, uygulanan mesleki çalışmalar ve ideal mesleki çalışmalar konusundaki metaforik görüşlerini ayrı bölümlerde açıklamışlardır. Bu nedenle uygulanan mesleki çalışmalara yönelik verilen cevaplar bir kategori, ideal mesleki çalışmalara yönelik verilen cevaplar da ayrı bir kategoride değerlendirilmiştir. Daha sonra "uygulanan mesleki çalışmalar" ve "ideal mesleki çalışmalar" kategorilerinde geliştirilen metaforlar ve özellikleri incelenerek değerlendirilmiş ve bu metaforlar; konusu, kaynağı ve metaforla ilgili açıklamalar dikkate alınarak çeşitli temalar altında gruplanmıştır.

Bunun sonucunda "Uygulanan Mesleki Çalışmalar" için üretilen metaforlardan sosyalleşme sürecini vurgulayanlar "sosyalleşme aracı olarak mesleki çalışmalar"; zaman kullanımını olumsuz yönde vurgulayanlar "boşa geçirilen zaman olarak mesleki çalışmalar"; eylemlerin sonuçsuzluğuna dikkat çekenler "sonuç doğurmayan eylemler olarak mesleki çalışmalar"; içeriğin yetersizliğine değinenler "içerik yoksunu olarak 
mesleki çalışmalar"; mesleki çalışmaların bir cezalandırma yöntemine dönüştüğünü vurgulayanlar "baskıcı/cezalandırıcı olarak mesleki çalışmalar"; soyut ve uygulanabilir olmadığını vurgulayanlar "uygulamada karşı1lığı olmayan mesleki çalışmalar"; belirli bir hedefin, amacın net bir biçimde tanımlanmadığını belirtenler "amaç yoksunu olarak mesleki çalışmalar"; yapılanların samimi ve gerçekçi olmadığına vurgu yapanlar "tiyatro olarak mesleki çalışmalar"; kararlara katılımın yetersiz olduğuna dikkat çekenler "kararlara katılımın olmadığı mesleki çalışmalar"; yapılanları birbirinin tekrarı olarak görenler "tekrar eden olarak mesleki çalışmalar" adı altında on temada gruplandırılmıştır.

"İdeal Mesleki Çalışmalar” için üretilen metaforlardan birlikte çalışmayı vurgulayanlar "takım çalışması olarak mesleki çalışmalar"; işe yarar sonuçlar doğurması gerektiğini belirtenler "fayda veren eylemler olarak mesleki çalışmalar"; motivasyonu vurgulayanlar "motive eden/güç veren olarak mesleki çalışmalar"; öğretici fonksiyonunu dikkat çekenler "öğretici olarak mesleki çalışmalar"; başarılması gereken zor bir görev olduğunun üzerinde duranlar "zor olanı başaran olarak mesleki çalışmalar"; kararlara katılımı vurgulayanlar "katılımc1/özerk olarak mesleki çalışmalar"; çok çalışmayı vurgulayanlar "çalışkan olarak mesleki çalışmalar"; ufuk açıcı yönüne dikkat çekenler "yol gösterici olarak mesleki çalışmalar"; soyut ve uygulanabilir olmadığını vurgulayanlar ise "ulaşılamaz olarak mesleki çalışmalar" olmak üzere dokuz temada gruplandırılmıştır.

Araştırma verilerinin geçerliğini sağlamaya ilişkin olarak veri analizi sürecinin nasıl yürütüldüğü açıklanmış ve araştırmada elde edilen metaforların ayrıntılı listelerine yer verilmiştir. Örnek metaforlar açıklamalarıyla birlikte ilgili temada belirtilmiştir. Araştırmanın güvenirliğini sağlamak için ise araştırmada ulaşılan kavramsal kategoriler ya da temaların altında yer alan metaforların söz konusu temayı temsil edip etmediğine ilişkin olarak uzman görüşüne başvurulmuştur. Uzmanların eleştirileri ve önerileri doğrultusunda yeniden düzenleme yapılmış ve bulgular bölümünün ilgili yerlerinde bu düzenlemelere yer verilmiştir.

\section{Bulgular}

Öğretmenlerin "uygulanan mesleki çalışmalar” hakkında sahip oldukları algı ile "ideal mesleki çalışmalar" hakkında tasarladıkları algılarını metaforlar aracılığıyla analiz etmeyi amaçlayan çalışmanın bu bölümünde elde edilen bulgulara yer verilmiştir. Öncelikle öğretmenlerin "uygulanan mesleki çalışmalar" hakkında hangi metaforları kullandıkları ve bu metaforları neden kullandıklarına yönelik bulgular yer almaktadır. İkinci aşamada "uygulanan mesleki çalışmalar"a yönelik üretilen metaforların hangi temalar altında toplandığına ilişkin bulgular sunulmuştur. 
Öğretmenlerin Uygulanan Mesleki Çalışmalara Ilişkin Metaforları ve Nedenleri

Öğretmenlerin, uygulanan mesleki çalışmalara ilişkin sahip oldukları metaforlar Tablo 2'de verilmiştir.

Tablo 2

Öğretmenlerin Uygulanan Mesleki Çalışmalara Ilişkin Metaforları

\begin{tabular}{|c|c|c|c|c|}
\hline & Olumsuz & & Olumlu & \\
\hline & Metaforlar & $f$ & Metaforlar & $f$ \\
\hline 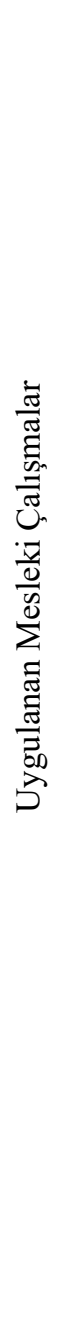 & $\begin{array}{l}\text { ömür törpüsü, çalar saat, erkek aslan, gürültücü saat, fare, } \\
\text { ayı, k1ş uykusu, süs yel değirmeni, Don Kişot, } \\
\text { kaplumbağa, bilinç kaybı, bayılma, hafiza kaybı, kum } \\
\text { saati, volta, tespih, tatil planı, sayılı gün, Don Kişot, dibi } \\
\text { delik kova, altı delik sürahi, Pinokyo, rulman, Murat 131, } \\
\text { Deli Dumrul, balık, uçmayan balon, kabarmayan hamur, } \\
\text { etkisiz eleman, Road Runner, kaplumbağa, meyvesiz } \\
\text { ağaç, su buharı, patinaj, havuz problemi, Survivor, } \\
\text { yağmur duası, galibiyet sevinci, Hitler, Külkedisinin } \\
\text { kardeşleri, sobanın üstünde geçen bir dakika, Erol Taş } \\
\text { kahkahası, virüs, yılan, zombi, doktor, akvaryumdaki } \\
\text { balık, Deli Dumrul, Çin işkencesi, hapishane, gardiyan, } \\
\text { bedel, içi boş kutu, boş bardak, boş teneke, Casper, boş } \\
\text { kaset, boş sürahi, boş şişe, içi boş, kütüphane, balon, } \\
\text { ahtapot, kargo paketi, boş enjektör, kahve muhabbeti, } \\
\text { yumurtlayan yumurta, süslü ambalaj, matruşka, Simurg, } \\
\text { adalet, uyuyan prenses, Casper, Aristo, ütopya, masal } \\
\text { ülkesi, gökten düşen } 3 \text { elma, serap, hayal, halisilasyon, } \\
\text { Herkül, Olimpos, Kara Murat, sandal, susuz varoş, bozuk } \\
\text { pusula, hedefi olmayan ok, geyik muhabbeti, Pazar } \\
\text { gezmesi, gidecek yeri olmayan tren, yolunu kaybeden } \\
\text { garip, Leyla'sını unutan Mecnun, meczup, deli, masal } \\
\text { kitab1, karagöz, Pinokyo, uçan mürekkep, Üç Silahşorlar, } \\
\text { Hansel ile Gratel, maskeli balo, kulis, sahne, sirk, } \\
\text { Mandrake, hipnoz, ilizyon, şapkadan çıan tavşan, } \\
\text { koyun, papağan, uyuyan güzel, Pinokyo, uzaktan } \\
\text { kumanda, ögrencilik, sunum, sürü, çoban, kalabalık, } \\
\text { dikensiz gül bahçesi, monolog, büyüklerimizin uygun } \\
\text { gördüğü, maymun, uçurtma, emir komuta, 12 hayvanlı } \\
\text { Türk takvimi, Gulyabani, dikili taş, yerinde sayan } \\
\text { koşucu, dönme dolap, hemstır çark, yel değirmeni, } \\
\text { değirmen taşı, çölde daireler çizen adam, labirent, çıkmaz } \\
\text { sokak, tarih, tekerleme, pembe dizi, tespih }\end{array}$ & 138 & $\begin{array}{l}\text { Heredot Cevdet, kafe, } \\
\text { muhabbet kuşu, okeye } \\
\text { aranan dördüncü, geyik } \\
\text { muhabbeti, çay, kahve, } \\
\text { sohbet, misafirlik, } \\
\text { gazete, magazin, kahve } \\
\text { falı }\end{array}$ & 12 \\
\hline
\end{tabular}

Öğretmenler uygulanan mesleki çalışmalara ilişkin toplam 150 metafor üretmişlerdir. Üretilen metaforlardan 6 tanesi (Don Kişot, tespih, Deli Dumrul, Pinokyo, Casper, kaplumbağa) farklı temalarda kullanılmıştır. Metaforlardan 138 tanesi olumsuzken sadece 12 tanesi olumludur. Burada dikkati çekici olan öğretmenlerin uygulanan mesleki çalışmalara ilişkin sahip oldukları metaforların çoğunun olumsuz olmasidir.

Öğretmenlerin, uygulanan mesleki çalışmalara ilişkin sahip oldukları metaforlar 10 tema altında sınıflandırılmıştır. Oluşturulan 10 temadan "sosyalleşme aracı olarak mesleki çalışmalar" teması olumlu iken, geri kalan temalar olumsuzdur. Aşağıda temalar ve bu temalar altında yer alan metaforlar ve nedenlerine yer verilmiştir: 
Sosyalleşme aracı olarak mesleki çalışmalar. Bu temada Heredot Cevdet, muhabbet kuşu, kafe, okeye aranan dördüncü, geyik muhabbeti, çay, kahve, sohbet, misafirlik, gazete, magazin, kahve falı olmak üzere 12 adet metafor yer almaktadır. Bu temadaki 12 meteforun her biri ayrı bir katılımcı tarafından ifade edilmiştir.

Muhabbet Kuşu: "Tüm yıl boyunca bir araya gelmeyen öğretmenler seminer döneminde bir araya geldiklerinde muhabbet ederler." (K12)

Kafe: "İnsanların gelip sohbet ettiği, yiyip içip eğlendikten sonra evlerine döndükleri yerdir. Seminer dönemlerinde buna benzer işler yapıp sosyalleşiriz.” (K27)

Herodot Cevdet: "Seminer çalışmaları yaz tatili boyunca sıkılan öğretmenler için sohbet muhabbet ortamı oluyor." (K54)

Geyik muhabbeti : "Okula gelip bütün gün sohbet ediyoruz bütün yılın yorgunluğu geçiyor." (K62)

Boşa geçen zaman olarak mesleki çalışmalar. Bu temada yer alan meteforların her biri ayrı bir katılımcı tarafından oluşturulmuştur. Katılımcılar ömür törpüsü, çalar saat, erkek aslan, gürültücü saat, fare, ayı, kış uykusu, süs yel değirmeni, Don Kişot, kaplumbağa, bilinç kaybı, bayılma, hafıza kaybı, kum saati, volta, tespih, tatil planı, sayılı gün olmak üzere 18 adet metafor üretmiştir.

Ömür Törpüsü : "İnsanı hayatından bezdiren, lanet okutan, imdat dedirten geçmek bilmeyen, ama boşa geçen zaman.” (K17)

Fare : "Mesleki çalışmalar zamanımızı kemiren bir faredir. Tıpkı farenin bir şeyleri kemirmesi gibi bu çalışmalar da zamanı boşa geçirdiğimiz anlamsız işlerdir." (K40)

Çalar saat : "Boş ve anlamsız geçen bu zamanın bitmesini bir çalar saatin çalmasını bekler gibi bekliyorum." (K119)

Erkek aslan : "Erkek aslan gibi pinekleyip zaman öldürüyoruz.” (K147)

Sonuç doğurmayan eylemler olarak mesleki çalışmalar.Bu temada Don Don Kişot, dibi delik kova, altı delik sürahi, Pinokyo, rulman, Murat 131, Deli Dumrul, balık, uçmayan balon, kabarmayan hamur, etkisiz eleman, Road Runner, kaplumbağa, meyvesiz ağaç, su buharı, patinaj, havuz problemi, Survivor, yağmur duası, galibiyet sevinci olmak üzere 20 adet metafor bulunmaktadır. Meteforların her biri farklı katılımcılar tarafindan ifade edilmiştir.

Don Kişot : "Don Kişot nasıl yel değirmenleri ile boşuna savaşıyorsa mesleki çalışmalar da boşuna bir çabadır." (K32)

Pinokyo : "Pinokyo gerçek bir çocuk olmak için bir sürü şey dener ama gerçek bir çocuk olamaz. Mesleki çalışmalarda bir sürü şey yapılır ama bir sonuç elde edilmez." (K47)

Dibi delik kova : "Sürekli bir şeyler yapılıyor içine atılıyor ama biriken bir şey yok." (K103)

Rulman : "Dön dolaş aynı sonuç, başladığın yerdesin. Elinde hiçbir şey yok.” (K135)

Baskıcı/cezalandırıcı olarak mesleki çalışmalar. $\mathrm{Bu}$ temada Hitler, Külkedisinin kardeşleri, sobanın üstünde geçen bir dakika, Erol Taş kahkahası, virüs, yılan, zombi, doktor, akvaryumdaki balık, Deli Dumrul, Çin işkencesi, hapishane, 
gardiyan, bedel olmak üzere 14 adet metafor bulunmaktadır. Bu temada katılımcılar tarafindan ortak kullanılan metefor yoktur.

Erol Taş Kahkahası : "Şu an var olan çalışmalar sırf birilerine eziyet ederek birilerini tatmin etmeye yönelik." (K25)

Kül Kedisi'nin Kötü Kardeşleri : “Kül Kedisi'nin kötü kardeşleri sırf ona acı çektirmek için onu sürekli çalıştırdıkları gibi seminer çalışmaları da öyle. Amaç sürekli baskı altında tutmak." (K50)

Hitler : "Hitlerin elindeki Yahudileriz sanki ne kadar zulüm etseler az." (K110)

Çin işkencesi : "Yavaş, küçük ama acı verici." (K126)

İçerik yoksunu olarak mesleki çalışmalar. Bu temada içi boş kutu, boş bardak, boş teneke, casper, boş kaset, boş sürahi, boş şişe, içi boş, kütüphane, balon, ahtapot, kargo paketi, boş enjektör, kahve muhabbeti, yumurtlayan yumurta, süslü ambalaj, matruşka olmak üzere 14 metafor üretilmiştir. Her bir katılımcının bu tema için ürettiği metefor farklıdır.

Kahve muhabbeti : "Kahvede yapılan konuşmalar daha anlamlı ve daha kapsamlıdır diyebilirim." (K4)

Boş Bardak : "Bardak içinde su varken anlamlıdır. Nasıl ki bardak içi dolu iken anlamlıdır seminer çalışmaları da var ama içi boş ve tıpkı bardak gibi anlamsız.” (K38)

Boş teneke : "Boş tenekeden çok ses gelir bizim seminerlerde boş. O yüzden bu kadar yaygara kopuyor." (K107)

Boş kaset : "Seminer çalışmalarında ne olduğu anlaşılmaz bir hırıltıdan başka bir ses duyamiyorum." (K126)

Uygulamada karşılığı olmayan mesleki çalışmalar. Bu temada katılımcılar tarafından Simurg, adalet, uyuyan prenses, casper, Aristo, ütopya, masal ülkesi, gökten düşen üç elma, serap, hayal, halisilasyon, Herkül, Olimpos, Kara Murat olmak üzere 14 adet metafor birer defa üretilmiştir. Tema ilk olarak "Hayalperest olarak mesleki çalışmalar" olarak isimlendirilmiş. Uzman görüşü dorultusunda temanın ismi "Uygulamada karşılığı olmayan mesleki çalışmalar" olarak değiştirilmiştir.

Simurg : "Anlatılanlar belki teoride doğru ama gerçek hayatta karşılığı olmayan, farazi söylemler." (K8)

Adalet : "Olması gerektiğine inanıyorum ama olmadığını biliyorum. Seminer çalışmalarında bahsedilen konular da pratiğe geçirilebilir değil.” (K68)

Halisilasyon : "Gerçekte olmayan şeyler bize gerçekmiş gibi gösterilmeye çalış1lıyor." (K82)

Herkül : "Herkül, varmış ama biz görmedik.” (K92)

Amaç yoksunu olarak mesleki çalışmalar. Bu temada katılımcılar tarafından Sandal, susuz varoş, bozuk pusula, hedefi olmayan ok, geyik muhabbeti, Pazar gezmesi, gidecek yeri olmayan tren, yolunu kaybeden garip Leyla'sını unutan Mecnun, meczup, deli olmak üzere 11 adet metafor birer kez üretilmiştir.

Pazar gezmesi : “Amaç gezmek, gidilecek yerin pek önemi yok. Seminerler de öyle amacımız seminer yapmak o kadar.” (K21) 
Bozuk pusula : "Bozuk pusula doğru yönü gösteremez. Hedefi net olmayan çalışmadan da bir şey ç1kmaz.” (K29)

Leyla'sını unutan Mecnun : "Bir şeyler yapıyoruz ama niçin yaptığımızı ne yaptı̆̆ımız bildiğimiz yok. Mecnun birini arıyor ama kimi aradığını unutmuş" (K44)

Hedefi olmayan ok : "Yayından ayrılmış ama nereye gideceğini bilmiyor." (K75)

Tiyatro olarak mesleki çalışmalar. Bu temada masal kitabı, karagöz, Pinokyo, uçan mürekkep, Üç Silahşorlar, Hansel ile Gratel, maskeli balo, kulis, sahne, sirk, Mandrake, hipnoz, ilizyon, şapkadan çıkan tavşan olmak üzere 14 metafor üretilmiştir. Bu temada ortak kullanılan metefor yoktur

Maskeli balo: "Bütün dünya bir sahne bizler de oyuncularız. Rolümüz bu oynuyoruz." (K14)

Mandrake : "Hokus pokus her şey çok güzel. Herkes memnun." (K58)

Kulis : "Sahneye çıkmadan önce roller prova ediliyor." (K72)

Sahne : "Her birimiz usta bir oyuncu. Bizlere biçilen rolleri oynuyoruz." (K86)

Kararlara katılımın olmadığı mesleki çalışmalar. Bu temada koyun, papağan, uyuyan güzel, Pinokyo, uzaktan kumanda, öğrencilik, sunum, sürü, çoban, kalabalık, dikensiz gül bahçesi, monolog, büyüklerimizin uygun gördüğü, maymun, uçurtma, emir komuta olmak üzere 18 adet metafor farklı katılımcılar tarafından üretilmiştir.

Uzaktan kumanda : "Bizlere bilinçsiz varlıklarmışız gibi davranıyorlar. İşlerine gelince açıp işlerine gelince kapatıyorlar.” (K129)

Sürü : "Sürüde koyunun sözü geçer mi? Çoban nereye sürü oraya. Ne derlerse yapiyoruz." (K132)

Monolog : "Bir kişi konuşuyor herkes onu dinliyor." (K140)

Öğrencilik : “Okul açıkken bizim öğrencilere yaptığımızı o zaman bize yapıyorlar "al bunu öğren” diyerek kimsenin fikrimizi aldığı yok. (K145)

Tekrar eden olarak mesleki çalışmalar. Bu temada katılımcılar tarafından 12 hayvanlı Türk takvimi, Gulyabani, dikili taş, yerinde sayan koşucu, dönme dolap, hemstır çark1, yel değirmeni, değirmen taşı, çölde daireler çizen adam, labirent, çıkmaz sokak, tarih, tekerleme, pembe dizi, tespih olmak üzere 15 adet metafor birer defa üretilmiştir.

Hemstır çarkı : "Her sene aynı şeyler kendimi bir çarkın içinde dönen bir fare gibi hissediyorum.” (K110)

Tekerleme : "Mesleki çalışmalar anlamsız tekrarlardan ibarettir." (K113)

Tarih : "Nasıl ki tarih tekerrürden ibaret bizim mesleki çalışmalar da tekrardan ibaret." (K123)

Pembe dizi : "Hep aynı şeyler ama sürekli yeni bölümleri çıkıyor.” (K125) 


\section{Öğretmenlerin ideal mesleki çalışmalara ilişkin metaforları ve nedenleri}

Öğretmenlerin, ideal mesleki çalışmalara ilişkin sahip oldukları metaforlar Tablo 3'de verilmiştir.

Tablo 3

Öğretmenlerin İdeal Mesleki Çalışmalara Ilişkin Metaforları

\begin{tabular}{|c|c|c|c|c|}
\hline & Olumlu & & Olumsuz & \\
\hline & Metaforlar & $\mathrm{f}$ & Metaforlar & $\mathrm{f}$ \\
\hline 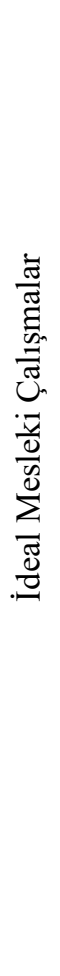 & $\begin{array}{l}\text { Aslan, şirinler, futbol takımı, Guliver, arı, zümre, orkestra, } \\
\text { arkadaş sohbeti, karınca, work shop, beyin firtınası, nalın çivisi, } \\
\text { çimento, gemi, halat oyunu, ameliyat ekibi, basketbol takımı, } \\
\text { milli takım, kovan, bayrak yarışı, ipek böceği, tohum, su dolu } \\
\text { bardak, içi dolu kutu, Mustafa Kemal, miladi takvim, } \\
\text { Alaaddin'in sihirli lambası, ağaç, su, toprak, meyve veren ağaç, } \\
\text { fabrika, arı, laboratuar, canlı organizma, fidan, tırtıl, buluş, cep } \\
\text { telefonu, baba, uçak, tuz, güneş, eyer, jaguar, piyano, Heman, } \\
\text { yunus, toprak, paylaşım, birlikte başarmak, başarma hissi, } \\
\text { elektrik, ateş, dost sohbeti, ağrı kesici, koltuk, empati, eğitim } \\
\text { danışmanı, Sokratik sorgulama, hayat kurtarıcı, yama, sevdiğin } \\
\text { biriyle geçen zaman, can simidi, koç, bulmaca, kütüphane, } \\
\text { Pamuk Prenses'teki ayna, Evliya Çelebi, Heredot, Robin Hood, } \\
\text { kitap, öğrenme sevinci, yaparak öğrenme, bilgi, internet, } \\
\text { öğretmen, belgesel, Tonguç, Fatih Sultan Mehmet, Kül Kedisi'ni } \\
\text { kurtaran prens, Atatürk, Mustafa Kemal Atatürk, Thomas } \\
\text { Edison, Spartakus, deniz yıldızını kurtaran çocuk, Steve Jobs, } \\
\text { aslan, Galile, aya gitmek, Aşı Veysel, roket, astronot, Stefen } \\
\text { Hawking, Superman, Atatürk, yunus, kanguru, Hasan Ali Yücel, } \\
\text { orman, aile, meclis, uzlaşı, tartışma, öneri, bakanlar kurulu, } \\
\text { Magna Carta, grev, Arı, dişi aslan, karınca, fabrika, Mercedes } \\
\text { motoru, çiftçi, Mozart, yedi cüceler, Kuva-i Milliye, harman yeri, } \\
\text { kırlangıç, ev hanımı, anne, Alfred Nobel, Atatürk, Jedi Usta, } \\
\text { zaman makinesi, heykeltıraş, uzman ekip, komutan, deniz feneri, } \\
\text { kutup yıldızı, karınca yuvası, kutup ş̧ı̆ğ, kılavuz, kullanma } \\
\text { kılavuzu, lider, öngörü, rehber, Kristof Kolomb, dost, GPS, } \\
\text { Navigasyon, radar }\end{array}$ & 141 & $\begin{array}{l}\text { Kaf Dağı'nın ardındaki } \\
\text { şato, mutlu son, peri } \\
\text { masalı, } \\
\text { karşılığını almak, adil } \\
\text { paylaşım, serap, rüya, } \\
\text { sanrı, sanal gerçeklik }\end{array}$ & 9 \\
\hline
\end{tabular}

Öğretmenler ideal mesleki çalışmalara ilişkin toplam 150 metafor üretmişlerdir. Metaforlardan 141 tanesi olumluyken sadece 9 tanesi olumsuzdur. Olumlu kategoride yer alan metaforlardan 5 tanesi (Aslan, arı, Atatürk, toprak, karınca) farklı temalarda kullanılmışlardır. Burada dikkat çekici olan öğretmenlerin ideal mesleki çalışmalara ilişkin sahip oldukları metaforların çoğunun olumlu olmasıdır.

Öğretmenlerin, ideal mesleki çalışmalara ilişkin sahip oldukları metaforlar 9 tema altında sınıflandırılmıştır. Oluşturulan 9 temadan "ulaşılmaz olarak ideal mesleki çalışmalar" teması olumsuzken geri kalan temalar olumludur. Aşağıda temalar ve bu temalar altında yer alan metaforlar ve nedenlerine yer verilmiştir:

Takım çalışması olarak ideal mesleki çalışmalar. Bu temada Aslan, şirinler, futbol takımı, Guliver, arı, zümre, orkestra, arkadaş sohbeti, karınca, work shop, beyin fırtınası, nalın çivisi, çimento, gemi, halat oyunu, ameliyat ekibi, basketbol takımı, milli takım, kovan, bayrak yarışı olmak üzere 20 adet metafor geliştirilmiştir. Meteforların her biri farklı bir katılımcı tarafından ifade edilmiştir. Tema ilk olarak "Takım oyunu olarak mesleki çalışmalar olarak adalandırılmış. Uzman görüşü doğrultusunda temanın ismi “Takım çaşışması olarak ideal mesleki çalışmar” olarak belirlenmiştir. 
Aslan : "Aslanlar grup halinde avlanırlar. Yalnız çalışmazlar yani. İdeal mesleki çalışmaların da grup halinde koordineli bir çalışma şeklinde yapılmalı.” (K12)

Şirinler : "Şirinlerin farklı özellikler taşırlar ama bir arada ve ortak bir amaç için, kendi ihtiyaçları olan bir amaç için çaba harcarlar. Onlar kararları birlikte alır, birlikte çalışır ve birlikte başarır." (K24)

Futbol takımı : "Mesleki çalışmalar bir takım oyunu gibi olmalı, birlikte çalışılıp, sonuç alınmal1." (K43)

Ar1 : "Arıların en yaptığı iş baldır ama balı tek başlarına yapmazlar bal bir kovanın ortak çalışmasının sonucudur.” (K52)

Fayda veren eylemler olarak ideal mesleki çalışmalar. Bu temada katılımcılar tarafından ipek böceği, tohum, su dolu bardak, içi dolu kutu, Mustafa Kemal, miladi takvim, Alaeddin'in sihirli lambası, ağaç, su, toprak, meyve veren ağaç, fabrika, arı, laboratuar, canlı organizma, fidan, tırtıl, buluş, cep telefonu, baba, uçak, tuz olmak üzere 22 adet metafor farklı katılımcılar tarafından geliştirilmiştir.

İpek Böceği : "Verimli, gerçekten faydalı, işlerin yapıldığı, formalite icabı evrak doldurmanın yapılmadığı, yeni döneme hazırlık amacıyla yetkin insanların önderliğinde amacına ulaşan çalışmaların yapıldığı, sonunda ipek böceğinin ürettiği ipek gibi düzgün işlerin çıktığı bir dönem olmalı.” (K30)

Tohum : "Tohumu ekersiniz ve sonunda elle tutulur yararlı bir sonuç elde edersiniz ve onu kullanırsinız". (K49)

Su dolu bardak : "Su bitki için ne kadar faydalı ise bu çalışmalar da öğretmenler için öyle olmal1." (K57)

İçi dolu kutu : "İçinden işe yarayan bir şey çıkmalı.” (K90)

Motive eden, güç veren olarak ideal mesleki çalışmalar. Bu temada güneş, eyer, jaguar, piyano, Heman, yunus, toprak, paylaşım, birlikte başarmak, başarma hissi, elektrik, ateş, dost sohbeti, ağrı kesici, koltuk, empati olmak üzere 15 adet metafor birer kez üretilmiştir.

Güneş : "Güneş bazı canlılar için besin kaynağı, bazı canlılar için mutluluk, güzellik kaynağıdır. En önemlisi de bütün canlılar için enerji kaynağı olmasıdır. Mesleki çalışmalar da bize enerji vermeli ve gerekli motivasyonu sağlamalıdır.” (K81)

Eyer : "Biz öğrencileri bir yerden alıp, istenen bir yere götürmeye çalışıyoruz. Mesleki çalışmalar bize bu gücü vermeli.” (K99)

Jaguar : "Mesleki çalışmalar Jaguar araba gibi insanı kendine çekmeli, cezp etmeli ki insan heyecanlansin, istesin.” (K107)

Empati : "Seminer çalışmaları ile kendimizi anlatabilmeli ve anlaşılabilmeliyiz bu bizi mesleki açıdan daha güçlü kılacaktır." (K140)

Öğretici olarak ideal mesleki çalışmalar. Bu temada eğitim danışmanı, Sokratik sorgulama, hayat kurtarıcı, yama, sevdiğin biriyle geçen zaman, can simidi, koç, bulmaca, kütüphane, Pamuk Prenses'teki ayna, Evliya Çelebi, Heredot, Robin Hood, kitap, öğrenme sevinci, yaparak öğrenme, bilgi, internet, öğretmen, belgesel, Tonguç olmak 21 metafor birer defa üretilmiştir. 
Eğitim Danışmanı : "Her gün bir konu belirleyip eğitim danışmanı önderliğinde, karşılıklı fikir alış verişiyle her günün öğretici ve keyifle geçmesini isterdim. Farklı bakış açıları, farklı fikirler ve deneyimler eminim daha verimli olurdu." (K60)

Sokratik Sorgulama :" Başlangıçta ne bilip bilmediğinizin belli olmadığı ama sonuçta pek çok şeyi ve ilişkiyi anladığınız, öğrenme isteği ile dolduğunuz gün boyu süren ama size çok kısa gelen öğretici bir sohbet.” (K70)

Hayat kurtarıcı hareket : "Bize hayat kurtaran pratik bilgiler verebilmeli." (K95)

Yama : "Seminerler öğretmenlerin eksikliklerini tamamlayıp, yeni şeyler öğretebilmeli.” (K131)

Zor olanı başaran olarak ideal mesleki çalışmalar. Bu temada Fatih Sultan Mehmet, Kül Kedisi'ni kurtaran prens, Atatürk, Mustafa Kemal Atatürk, Thomas Edison, Spartakus, deniz yıldızını kurtaran çocuk, Steve Jobs, aslan, Galile, aya gitmek, Aşık Veysel, roket, astronot, Stefen Hawking olmak üzere 15 adet metafor geliştirilmiştir. Bu temada herbir katılımcı ayrı bir metefor üretmiştir.

Fatih Sultan Mehmet :" Mesleki çalışmalar İstanbul'un Fethi gibi büyük ve anlamlı bir işi başarabilmelidir." (K19)

Kül Kedisi'ni kurtaran Prens : “Tek bir ayakkabı ile kapı kapı dolaşan prens Kül Kedisi'ni kurtarıp prenses yapar. Bizim de mesleki çalışmalarla zor olanı başarıp mesleki anlamda bizi ileriye taşıyacak işlere ihtiyacımız var.” (K36)

Spartakus : "Öğretmenlik ve eğitmek iddialı bir iştir bu nedenle yaptı̆̆ımız seminerle de önemli bir işi başarabilmeliyiz.” (K65)

Aşı1k Veysel : “Onun da koşulları çok uygun değildi ama başardı, sesini duyurdu. Çok zor bir işi başardı. (K103)

Katılımcı/özerk olarak ideal mesleki çalışmalar. $\mathrm{Bu}$ temada Süperman, Atatürk, yunus, kanguru, Hasan Ali Yücel, orman, aile, meclis, uzlaşı, tartışma, öneri, bakanlar kurulu, Magna Carta, grev olmak üzere 14 metafor üretilmiştir. Bu temada her bir metefor farklı bir katılımcı tarafından geliştirilmiştir.

Süpermen : "İstediğin yerde, istediğin çalışmayı yapmak düşüncesi bile beni daha mutlu ve verimli kılıyor. Başkalarının istediği çalışmayı değil, kendi istediğim çalışmaları yapmak istiyorum.” (K93)

Atatürk : "Halkın içinden gelen lider, halkın sorunlarına onların da katılımlarını ve fikirlerini alarak özgün çözümler bulunmasını kolaylaştırır. Mesleki çalışmalarda öğretmenlerin fikirleri alınmalı, onların katılımı ve kendilerine özgü biçimlendirmeleri ile gerçekleştirilmelidir.” (K110)

Yunus : "Yunuslar gibi bizlerde sürekli iletişim halinde olmalı ve birbirimizi dinlemeliyiz. Seminerlerde ne yapılacağına birlikte karar vermeliyiz.” (K119)

Magna Carta : "Mesleki çakışmalar kaynağını bizim fikirlerimizden ve ihtiyaçlarımızdan almalıdır.” (K128)

Çalışkanlık olarak ideal mesleki çalışmalar. Bu temada katılımcılar tarafından arı, dişi aslan, karınca, fabrika, Mercedes motoru, çiftçi, Mozart, yedi cüceler, Kuva-i Milliye, harman yeri, kırlangıç, ev hanımı, anne, Alfred Nobel olmak üzere 14 metafor birer defa geliştirilmiştir. 
Ar1 : "Arılar hiç boş kalmaz bütün zamanları ve firsatları bal yapmak yani çalışmak için kullanırlar. Mesleki çalışmalarda da fursatlar değerlendirilmeli çok çalışılmalıdır." (K115)

Dişi aslan : "Aslan sürülerinde erkek aslan avlanmaz, dişi aslan ise hem yavruları büyütür hem de sürü için avlanır. Seminer çalışmaları mevcut hali ile erkek aslana benzerken olması gereken dişi aslan gibi çalışkan olmaktır.” (K122)

Karınca : "İdeal mesleki çalışmalar karınca gibi çalışkan ve üretken olmalıdır.” (K133)

Mercedes motoru : "Seminer çalışmalarında öyle bir düzen kurulmalı ki Mercedes motoru gibi tıkır tıkır çalışsın." (K145)

Yol gösterici olarak mesleki çalışmalar. Bu temada katılımcılar tarafından Atatürk, Jedi Usta, zaman makinesi, heykeltıraş, uzman ekip, komutan, deniz feneri, kutup yıldızı, karınca yuvası, kutup 1şı̆ğ, kılavuz, kullanma kılavuzu, lider, öngörü, rehber, Kristof Kolomb, dost, GPS, Navigasyon, radar olmak üzere 20 adet metafor birer kez üretilmiştir.

Atatürk : "Mesleğimize dair umudumuzun bittiği şu günlerde bize Atatürk gibi yol göstersin" (K39)

Deniz feneri : "Her kafadan bir sesin çıktığı bu ortamda yolumuzu aydınlatacak bir fenere ihtiyacimiz var." (K110)

Kristof Kolomb : "Kendi Amerika'mızı arıyoruz ama bizi oraya götürecek bir kâşifimiz yok, okyanusta kaybolduk.” (K119)

Radar : Etrafta bir sürü şey var ama ne önemli ne önemsiz belli değil bizi bir radar lazım ne önemli ne önemli değil anlayalım.” (K128)

Ulaşılamaz olarak ideal mesleki çalışmalar. Bu temada katılımcılar tarafindan Kaf Dağı'nın ardındaki şato, mutlu son, peri masalı, emeğinin karşılığını almak, adil paylaşım, serap, rüya, sanrı, sanal gerçeklik olmak üzere 9 adet metofor geliştirilmişidir. Temedaki her bir metefor farklı katılımcılar tarafından üretilmiştir.

Kaf Dağının Ardındaki Şato : "Olması gereken seminer çalışmaları Kaf Dağı'nın ardındaki masalsı şato gibi az gitsen uz gitsen dere tepe düz gitsen de ulaşılamaz, erişilemez bir yer." (K83)

Mutlu Son : "Mutlu son ancak kurgulanan şeylerde olur. Gerçekte hayatta mutlu son olmaz. Seminer çalışmaları da gerçek hayattadır. O zaman ideal olan seminer çalışmasına ulaşmak imkânsızdır.” (K136)

Serap : "Bize aradığınız şey bu diyorlar gidip bakıyoruz o şey her yerde olan kumdan başka bir şey değil.” (K143)

Sanal gerçeklik : "Gerçekmiş gibi ama gerçek değil” (K148)

\section{Tartışma, Sonuç ve Öneriler}

Öğretmenlerin mesleki çalışmalara yönelik düşüncelerini metaforlar yolu ile belirlemeye yönelik bu araştırmada birkaç önemli bulguya ulaşılmıştır. Üretilen metafor sayılarına bakılınca "sonuç doğurmayan eylemler olarak mesleki çalışmalar" teması için 20 metafor; "boşa geçen zaman olarak mesleki çalışmalar" teması için 18 metafor; "içerik yoksunu olarak mesleki çalışmalar" teması için 16 metafor; "kararlara katılımın olmadığı mesleki çalışmalar" teması için 16 metafor; "tekrar eden olarak mesleki 
çalışmalar" teması için 15 metafor; "uygulamada karşılığı olmayan mesleki çalışmalar" teması için 14 metafor; "baskıcı/cezalandırıcı olarak mesleki çalışmalar" teması için 14 metafor; "tiyatro olarak mesleki çalışmalar" teması için 14 metafor; "sosyalleşme aracı olarak mesleki çalışmalar" teması için 12 metafor; "amaç yoksunu olarak mesleki çalışmalar" teması için de 11 metafor üretilmiştir. Öğretmenlerin "uygulanan mesleki çalışmalar" kategorisinde ürettikleri metaforların çok büyük bir bölümü olumsuzdur. Bu kategoride üretilen metaforların tematik dağılımına bakıldığında sadece "sosyalleşme aracı olarak mesleki çalışmalar" temasının olumlu metaforlardan oluştuğu dolayısıyla bu temanın olumlu olduğu görülür. Bununla birlikte üretilen 150 metafordan sadece 12'sinin bu tema içinde olması, öğretmenlerin genel olarak uygulanan mesleki çalışmaları benimsemedikleri şeklinde yorumlanabilir. Başka bir anlatımla öğretmenlerin mevcut mesleki çalışmaları, içerik, planlama ve uygulama aşamasında fikirlerinin alınmaması nedeniyle kendini sürekli tekrar ederek adeta bir cezalandırma aracına dönüşen; gerçeklikten kopuk olması nedeniyle de işlevsel amaçları ve sonuçları olmayan ama oynayarak zaman kaybettikleri mizansenler olarak görme eğiliminde oldukları söylenebilir. Bu bağlamda elde edilen sonuçlar daha önceki araştırmalarda elde edilen, eğitim verecek kişilerin uzman olmadığı, uygulamanın gayri ciddi olduğu ve uygulanan programın ihtiyacı karşılamadığı (Gülmez, 2004; Özen, 2006; Saka, 2005; Tok \& Tok, 2009); hizmet içi eğitim ihtiyaçlarının belirlenmesinde öğretmen görüşlerine yer verilmediği ve planlamanın eksik olduğu (Aslan, 2015; Büyükcan, 2008; Demirkol, 2004; Direk, 2012; Özen, 2006; Saka, 2005; Sicak \& Parmaksız, 2016); eğitim faaliyetlerinde kullanılan materyallerin eksik, çalışma ortamının elverişsiz, fiziki ve teknolojik olanakların yetersiz olduğu (Aslan, 2015; Büyükcan, 2008; Özen, 2006); eğitim faaliyetlerinin öğretmenlerin ihtiyaçları doğrultusunda düzenlenmediği, ayrıca biçim ve içerik yönünden yetersiz olduğu (Gökyer, 2012; Özsavc1, 2015; Sıcak \& Parmaksız, 2016); eğitim çalışmalarının öğretmenlerin mesleki gelişimine katkısının teorik düzeyde olduğu ve uygulamanın eksik olduğu (Aslan, 2015; Sıcak \& Parmaksız, 2016); eğitim faaliyetlerinin değerlendirme sürecinin yetersiz olduğu (Saka, 2005; Sicak \& Parmaksı, 2016); eğitim sürecinde işbirliği ve motivasyonun sağlanmadığı (Büyükcan, 2008) bulguları ile paralellik göstermektedir. Gerek önceki araştırmaların bulguları gerekse bu araştırmanın sonuçları birlikte düşünüldüğünde mevcut hali ile mesleki çalışmalardan umulan faydaların elde edilmesinin ne denli güç olduğu görülebilir.

"İdeal mesleki çalışmalar” kategorisinde geliştirilen metaforların sayısal dağılımına bakıldığında "fayda veren eylemler olarak mesleki çalışmalar" teması için 22 metafor; "öğretici olarak mesleki çalışmalar" teması için 21 metafor; "takım çalışması olarak mesleki çalışmalar" teması için 20 metafor; "yol gösterici olarak mesleki çalışmalar" teması için 20 metafor; "motive eden/güç veren olarak mesleki çalışmalar" teması için 15 metafor; "zor olanı başaran olarak mesleki çalışmalar" teması için 15 metafor; "katılımc1/özerk olarak mesleki çalışmalar" teması için 14 metafor; "çalışkanlık olarak ideal mesleki çalışmalar" teması için 14 metafor; "ulaşılamaz olarak mesleki çalışmalar" teması için de 9 metaforun üretildiği görülür. "İdeal mesleki çalışmalar" kategorisinde geliştirilen metaforların tematik dağılımına bakıldığında ise sadece "ulaşılamaz olarak ideal mesleki çalışmalar" temasının olumsuz metaforlardan oluştuğu, dolayısıyla olumsuz bir tema olduğu görülür. "İdeal mesleki çalışmalar" kategorisinde geliştirilen 150 metaforun sadece 9 tanesi bu olumsuz tema içinde yer 
almaktadır. Bu durum "uygulanan mesleki çalışmalar" kategorisinde geliştirilen metaforların çoğunun olumsuz olduğu düşünüldüğünde oldukça anlamlı gözükmektedir. $\mathrm{Bu}$ bağlamda, öğretmenlerin kafasındaki mesleki çalışmalarla, uygulamadaki mesleki çalışmalar arasında oldukça büyük bir farklılığın olduğu söylenebilir. Öğretmenler mevcut mesleki çalışmaları benimsememelerine rağmen; zihinlerinde olması gereken mesleki çalışmaların taşıması gereken özelliklerine yönelik birtakım fikirler taşımaktadırlar. "İdeal mesleki çalışmalar" kategorisinde geliştirilen metaforların oluşturduğu temalar 1şı̆̆ında öğretmenlerin, kendi kendini yöneten takımlar olarak kendileri için meydan okuma niteliğinde olan zorlu fakat anlamlı buldukları görevleri beraberce çok çalışarak başarabilecekleri ve mesleki bilgi ve deneyimlerini arttırarak geleceğe dönük ufuk açıcı kazanımlar elde edebilecekleri bir mesleki çalışma formasyonu bekledikleri sonucuna varılabilir. Elde edilen sonuçlar benzer araştırmalarda elde edilen, hizmet içi eğitim uygulamalarına katılımın gönüllülük esasına dayalı olması gerektiği (Turgut, 2012); mesleki gelişime ve çağa ayak uydurabilmek için hizmet içi eğitimin ihtiyaç olduğu (Aslan, 2015; Can, 2004; Gültekin \& Çubukçu, 2008; Gültekin, Çubukçu \& Dal, 2012; Günbay1 \& Taşdöğen, 2012; Güneş, 2006; Nemli, 2017; Özavc1, 2015); eğitimcilerin yetkin, fiziki ve teknolojik donanımın yeterli olması gerektiği (Günbayı \& Taşdöğen, 2012; Özavc1, 2015; Turgut, 2012) sonuçları ile paralellik göstermektedir.

"Uygulanan mesleki çalışmalar" kategorisindeki ve "ideal mesleki çalışmalar" kategorisindeki sonuçlar birlikte değerlendirildiğinde, öğretmenlerin mevcut haliyle mesleki çalışmaları sonuç vermeyen eylemler ve boşa giden zaman olarak; ideal mesleki çalışmaları ise öğretici ve fayda sağlayan sonuçlar doğuran eylemler olarak gördükleri söylenebilir. Bu sonucu öğretmenlerin mesleki çalışmaları kendilerini geliştirmek için bir araç olarak görmek istedikleri ama uygulamada bunu karşılayamadıkları şeklinde değerlendirerek, öğretmenlerin gelişmeye ve öğrenmeye açık oldukları şeklinde de yorumlamak mümkündür.

Sonuç olarak mesleki çalışmaların mevcut hali ile sürdürülmesi yerine; içeriğini, zamanlamasını ve yöntemini her okulun kendi koşul ve ihtiyaçlarına göre belirleyeceği ve öğretmenlerin aktif katılımının sağlandığı çalışmalara dönüştürülmesi faydalı olabilir. Ağırlıklı olarak öğretmenin ve bir bütün olarak okulun sürece etkin katılımı, daha özgün ve okulun ihtiyaçlarına yönelik sonuçlar elde edilmesine katkı sağlayabilir. $\mathrm{Bu}$ ise bireysel boyutta ögretmenlerin yaptığı işi anlamlı bularak kendilerini güçlü hissetmelerini ve öğrenmeyi öğrenme etkinliklerini desteklerken, kurumsal boyutta da okulların öğrenen örgütlere dönüşmesinde etkili olabilir. Bu amaçla aşağıdaki öneriler geliştirilmiştir:

1. Mesleki çalışma konular merkezi olarak planlanmak yerine her okulun kendi planını yapmasına izin verilmelidir.

2. Mesleki çalışmalarda konu seçilirken okulun yaşadığı güncel problemlere dayalı konular seçilmelidir.

3. Yönetici ve öğretmenler kendi kendini yöneten takımlar olarak kendi mesleki çalışmalarını planlayabilmelidir.

4. Mesleki çalışmalar farklı konularda geliştirilen proje bazlı çalışmalar olabilir.

5. Farklı okullardaki yönetici ve öğretmenlerin deneyimlerinin paylaşılması mesleki çalışmaların kapsamına dâhil edilmelidir. 
6. Yönetici ve öğretmenlerin eğitimle ilgili bilimsel yayınları paylaştıkları etkileşim grupları çalışmaların kapsamına dahil edilebilir. Bu nedenle üniversitelerce oluşturulan bilimsel içeriğin bilim uzmanı olmayan eğitimciler için de anlaşılabilir olması üretilen bilginin eyleme dönüşmesine katkı sağlayabilir.

7. Yönetici ve öğretmenlerin bilimsel toplantı ve kongrelere katılımının her açıdan desteklenerek edinilecek bilgi ve deneyimin mesleki çalışmalar kapsamında paylaşılması sağlanmalıdır. 


\section{Summary}

Introduction: Our age, the so-called information age, is a period in which the paradigms could be old-fashioned in a very short time and dizzying changes are experienced with the impact of the produced information and technology. Only the learning organizations consisting of the learning individuals can keep up with the change. Özden (2008) describes the learning organization as a dynamic structure that can renew itself with the ability of learning from its own experiences. Learning organizations can be established and operated through the individuals and teams that learned how to learn. Inam (2014) describes the concept of learning to learn as a stance toward reality inside and outside of us and as a lifestyle; he emphasizes that learning to learn is not possible for the people who does not review their life experiences.

Occupational efforts in our legislation can contribute to teachers to become the individuals that learning to learn and contribute to the schools in transformation to be learning organizations. It is stated that these professional efforts (Article 38, the Regulation of the Ministry of Education on Pre-school and Primary School Institutions) are organized in order to improve the pre-school and primary school principals' and teachers' knowledge and manners about the fields of general culture, special education and pedagogical formation and to help them gain new skills (Ministry Of National Education - MEB, 2014).

Purpose and Significance: We try to find answers to the following questions in this study in order to analyze teachers' perceptions on "existing occupational practices" and "ideal occupational practices" through the metaphors:

- Which metaphors do the teachers use about the "existing occupational practices"?

- What are the themes that the metaphors -about the "existing occupational practices"- group under considering their common features?

- Which metaphors do the teachers use about the "ideal occupational practices"?

- What are the themes that the metaphors -about the "ideal occupational practices"-group under considering their common features?

Method: This study is a qualitative research to describe a situation. The study was carried out with the participation of 150 teachers in Muratpaşa District of Antalya Province. The research data were collected through the (survey) forms consisting of two parts. The first part consists of demographic information and the second part consists of the metaphors the participants have about the occupational practices.

The content analysis was used to analyze the data. In this study, "categorical analysis technique" was used for content analysis. The answers given to "existing occupational practices" and "ideal occupational practices" were categorized separately. Afterwards, we examined the metaphors and their features that were developed in both categories and these metaphors were grouped under various themes taking into consideration their subject, source and explanations related to the metaphors. 
Results: Teachers produced 150 metaphors related to the existing occupational practices. 138 of the metaphors are negative while only 12 of them are positive. The metaphors related to the existing occupational practices have been classified under 10 themes. Only one theme - "occupational practices as socializing tools" - is positive while the rest of these 10 themes are all negative. The themes are listed below:

Occupational practices as socializing tools,

Occupational practices as wasted time,

Occupational Practices as fruitless actions,

Occupational Practices as oppressive/punitive actions,

Occupational Practices as content lacking actions,

Occupational practices that is meaningless in practice,

Occupational Practices as purposeless/pointless actions,

Occupational Practices as theatre,

Occupational Practices in which there is no participation in decision-making,

Occupational Practices as recurring actions.

Teachers produced 150 metaphors related to the ideal occupational practices. 141 of the metaphors are positive while only 9 of them are negative. The metaphors related to the ideal occupational practices have been classified under 9 themes. Only one theme - "occupational practices as unattainable actions" - is negative while the rest of these 9 themes are all positive. The themes are listed below:

Ideal occupational practices as team work,

Ideal occupational practices as benefit-providing actions,

Ideal occupational practices as motivating and energizing actions,

Ideal occupational practices as instructive actions,

Ideal occupational practices as the actions achieving difficulties,

Ideal occupational practices as participant/autonomous,

Ideal occupational practices as industriousness,

Ideal occupational practices as lodestar/pathfinder,

Ideal occupational practices as unattainable actions.

Discussion and Conclusions: The teachers who participated in the research produced mostly negative metaphors related to the "existing occupational practices. This situation can be interpreted as they generally do not internalize the existing practices. The vast majority of the metaphors related to the "ideal occupational practices" are positive. This makes a sense taking into consideration that the majority of the metaphors related to the "existing occupational practices" category are negative. In this context, it can be said that there is a big difference between the existing occupational practices and the ideal ones in teachers' minds. Evaluating the results in both categories together, it can be said that the teachers see the existing occupational practices as wasted time and fruitless/inconclusive actions, while they see ideal occupational practices as instructive actions that give rise to useful results. It is possible to interpret these results as the following: teachers are open to learning and development; they want to see the 
occupational practices as a tool for developing themselves; however, they cannot find this opportunity in practice.

As a result, it is possible to get useful results from occupational practices should their contents, timing and methods are determined considering each school's own needs and conditions with the participation of teachers instead of maintaining these practices in their current form. To this end, the following recommendations have been suggested as possible efforts:

1. Each school should be permitted to make its own plan instead of centrally planned occupational study subjects.

2. Selection of the subjects for occupational practices should be carried out based the school's existing problems.

3. School administrators and teachers should be able to plan their own occupational practices as self-governing teams.

4. Occupational practices can be project-based activities that can be developed considering different subjects.

5. Ensuring the exchange of experiences of the administrators and teachers in different schools should be included in the scope of these practices.

6. It can be useful to form interaction groups through which the administrators and teachers can share educational scientific publications within the scope of these practices. Therefore, universities' creating scientific content that is understandable for non-specialist educators can make contributions in transforming knowledge into actions.

7. Administrators and teachers, in every aspect, should be supported to participate in scientific meetings and congresses; the knowledge and experience to be gained in these platforms should be shared in the scope of occupational practices. 


\section{Kaynakça}

Althusser, L. (2016). İdeoloji ve devletin ideolojik aygıtları. (A. Tümertekin, Çev.). İstanbul: İthaki Yayınları.

Aslan, M. (2015). Türkiye milli eğitim sistemindeki değişmeler ışı̆̆ı̆nda "hizmet içi eğitim” (Yayımlanmamış Yüksek Lisans Tezi). İstanbul Aydın Üniversitesi, Sosyal Bilimler Enstitüsü, İstanbul.

Bolman, L. G., \& Deal, T. E. (2013). Organizasyonları yeniden yapılandırmak. (A. Aypay \& A. Tanrı̈ğen, Çev.). Ankara: Seçkin Yayınları.

Büyükcan, Y. (2008). Illkögretim okullarındaki hizmet içi ĕgitim seminerlerinin ögretmenlere yararlılı̆̆ (Yayımlanmamış Yüksek Lisans Tezi). Hacettepe Üniversitesi, Sosyal Bilimler Enstitüsü. Ankara.

Can, N. (2004). Öğretmenlerin geliştirilmesi ve etkili öğretmen davranışları, Soysal Bilimler Dergisi, 16, 103-109.

Cerit, Y. (2004). Küreselleşmenin eğitimsel etkileri. Abant İzzet Baysal Üniversitesi Sosyal Bilimler Dergisi, 2(9), 47-63.

Çelikten, M. (2015). Milli Eğitim Bakanlığı e-hizmet içi eğitim uygulamalarında ögretmen görüşlerine göre karşılaşılan sorunlar ve çözüm önerileri (Yayımlanmamış Yüksek Lisans Tezi). Okan Üniversitesi, Sosyal Bilimler Enstitüsü, İstanbul.

Demirkol, M. (2004). İlköğretim okullarında öğretmenlere yönelik okul-temelli hizmetiçi eğitim etkinliklerinin değerlendirilmesi (Yayımlanmamış Yüksek Lisans Tezi). Anadolu Üniversitesi, Eğitim Bilimleri Enstitüsü, Eskişehir.

Dinçer, M., (2003). Eğitimin toplumsal değişme sürecindeki gücü. Ege Eğitim Dergisi, $3(1), 102-112$.

Direk, A. (2012). Illköğretim okullarında düzenlenen mesleki çalışma uygulamalarına ilişkin yönetici ve ögretmen görüşleri, algı ve beklentileri (Yayımlanmamış Yüksek Lisans Tezi). Abant İzzet Baysal Üniversitesi, Eğitim Bilimleri Enstitüsü, Bolu.

Gökyer, N., (2012). Öğretmenlerin hizmet içi eğitim sürecinde karş1laştıkları sorunlar ve öncelikli ihtiyaç duydukları konular. Türkiye Sosyal Araştırmalar Dergisi, 162, 234-265.

Gülmez İşler, S. (2004). Sinıf öğretmenlerine uygulanan hizmet içi ĕgitim programlarının etkililiğine ilişkin öğretmen görüşlerinin belirlenmesi (Yayımlanmamış Yüksek Lisans Tezi). Sakarya Üniversitesi, Sosyal Bilimler Enstitüsü, Sakarya.

Gültekin, M., \& Çubukçu, Z. (2008). İlköğretim öğretmenlerinin hizmet içi eğitime ilişkin görüşleri, Sosyal Bilimler Dergisi, 19, 185-201.

Gültekin, M, Çubukçu, Z., \& Dal, S. (2010). İlköğretim öğretmenlerinin eğitim öğretimle İlgili hizmet içi eğitim gereksinimleri, Selçuk Üniversitesi Ahmet Keleşoğlu Eğitim Fakültesi Dergisi, 29, 131-152.

Günbayı, İ., \& Taşdöğen, B. (2012). İlköğretim okullarında çalışan öğretmenlerin hizmet içi eğitim programları üzerine görüşleri: bir durum çalışması. Insan ve Toplum Bilimleri Araştırmaları Dergisi, 1(3), 87-117. 
Güneş, M. (2006). İlköğretim okulu öğretmenlerinin hizmet içi eğitim programlarına katılmayı isteme ve istememe nedenleri (Yayımlanmamış Yüksek Lisans Tezi). Hacettepe Üniversitesi, Sosyal Bilimler Enstitüsü, Ankara.

Hoskins, B., \& Fredriksson, U., (2008). Learning to learn: What is it and can it be measured?. Luxembourg: European Communities.

İnam, A. (2014, Aralık 28). Öğrenmeyi öğrenme. http://www.phil.metu.edu.tr/ahmetinam/ogrenme.htm sayfasından elde edilmiştir.

Lasi, H., \& Kemper, H.G., (2014). Industry 4.0. Business \& Information Systems Engineering, 4, 239-242.

Merriam, S.B. (2013). Nitel araştırma desen ve uygulama için bir rehber. (S. Turan Çev. Ed.). Ankara: Nobel Yayınları.

Milli Eğitim Bakanlığı. (2014). Milli Eğitim Bakanlığı okulöncesi eğitim ve ilköğretim kurumlari yönetmeliği. http://www.meb.gov.tr sayfasından elde edilmişitir.

Milli Eğitim Bakanlığı. (2016). Ortaöğretim kurumları yönetmeliği. http://www.meb.gov.tr sayfasından elde edilmişitir.

Morgan, D. L. (1997). Focus groups as qualitative research. California: SAGE.

Nartgün, Ş., \& Kaya, A. (2016). Özel okul velilerinin beklentileri doğrultusunda okul imajı oluşturma. Ĕgitim ve Öğretim araştırmaları Dergisi, 5(2), 153-167.

Nemli, S., (2017). Illkokul öğretmenlerinin hizmet içi eğitim programlarının etkililiğine yönelik görüşleri (Yayımlanmamış Yüksek Lisans Tezi). Sakarya Üniversitesi, Eğitim Bilimleri Enstitüsü, Sakarya.

Özden, Y. (2008). Ĕgitimde yeni dĕgerler. Ankara: Pegem Akademi.

Özen, R. (2006). İlköğretim okulu öğretmenlerinin hizmet içi eğitim programlarının etkilerine ilişkin görüşleri: Düzce ili örneği. Abant İzzet Baysal Üniversitesi Ĕ̆itim Fakültesi Dergisi, 6(2), 141-160.

Özkan, Ü. (2018). Ortaokul 5. sinıf velilerinin okul yönetiminden beklentileri (Yayımlanmamış Yüksek Lisans Tezi). Pamukkale Üniversitesi, Eğitim Bilimleri Enstitüsü, Denizli.

Patton, M. Q. (2014). Nitel araştırma ve değerlendirme Yöntemleri. (M. Bütün \& S. B. Demir, Çev.). Ankara: Pegem Akademi.

Saka, F. (2005). Milli Ĕ̆itim Bakanlı̆̆ hizmet içi eğitim etkinliklerinin meslek lisesi ögretmenleri tarafindan değerlendirilmesi (Yayımlanmamış Yüksek Lisans Tezi). Gazi Üniversitesi, Eğitim Bilimleri Enstitüsü, Ankara.

Seferoğlu, S. S. (2004). Öğretmenlerin hizmet içi eğitiminde yeni yaklaşimlar. Akdeniz. Üniversitesi Eğitim Fakültesi Dergisi, 1(1), 83-95.

Sıcak, A., \& Parmaksız, R. Ş. (2016). İlköğretim kurumlarındaki mesleki çalışmaların etkililiğinin değerlendirilmesi. Inönü Üniversitesi Ĕ̆itim Fakültesi Dergisi, 17(1), 17-33.

Tezcan, M. (1997). Eğitim sosyolojisi. Ankara: Ankara Üniversitesi Eğitim Bilimleri Fakültesi Yayinlari No: 150.

Tok, T.N., \& Tok, Ş. (2009). Opinions of teachers on effectiveness of IST programs. Procedia Social and Behavioral Sciences, 1, 124-128. 
Turgut, S. (2012). Illköğretim sınıf öğretmenlerinin hizmet içi eğitim ihtiyaçlarının saptanması (Yayımlanmamış Yüksek Lisans Tezi). Mehmet Akif Ersoy Üniversitesi, Eğitim Bilimleri Enstitüsü, Burdur.

Yıldırım, A., \& Şimşek, H. (2006). Sosyal bilimlerde nitel araştırma yöntemleri. Ankara: Seçkin Yayıncılık. 